\title{
Determination of Nuclear Transcription Factor Activity Using a Modified Electrophoretic Mobility Shift Assay
}

\author{
Yong Wang ${ }^{1,2}$, Wenhua Huang ${ }^{1}$, Daizhi Peng ${ }^{1 *}$ and Yuanbin $\mathrm{Hu}^{1}$ \\ ${ }^{I}$ Institute of Burn Research; State Key Laboratory of Trauma; Burns and Combined Injury; Southwest Hospital; \\ Third Military Medical University; 400038; Chongqing - China. ${ }^{2}$ Department of Rheumatology; Southwest \\ Hospita; Third Military Medical University; 400038; Chongqing - China
}

\begin{abstract}
In this work, several major procedures of the electrophoretic mobility shift assay (EMSA) were modified including swift extraction of the nucleic protein, labeling of the probe and radioautography. The modified assay required shorter time, simplified the nucleic protein extraction, increased the radioactivity of the labeling probe, skipped the tedious process of gel drying, and produced clear images. Its results were comparable, reproducible and stable. It thus has merited for wide application.
\end{abstract}

Key words: Nuclear transcription factor, electrophoretic mobility shift assay, methodology, modification

\section{INTRODUCTION}

The electrophoretic mobility shift assay (EMSA, also known as gel retardation assay or band shift assay) is the simplest and, perhaps, the most widely used method for investigating the proteinnucleic acid interactions (Lane et al., 1992). This technique originated from the early work on the rRNA-protein interaction (Dahlberg et al., 1969; Shaup et al., 1970), and its widespread use dates from its development for the studies on the transcriptional regulation in the bacteria (Fried and Crothers, 1981; Garner and Revzin, 1981). It is based on the observation that the protein bound to the DNA or RNA fragment usually leads to a reduction in the electrophoretic mobility of the fragment in the nondenaturing polyacrylamide or agarose gels. The nucleic acid probe is usually labeled by the radioisotope.

In 1983, Dignam et al (1983) firstly built up the technique of the nucleic protein extraction, followed by a multitude of such protocols for the EMSA. In China, over recent years, these techniques have been utilized to probe the activity of the nuclear transcription factors in the cellular signal transduction pathways. However, these protocols are tedious and difficult to grasp. It is therefore imperative to seek a simple, stable, and reliable EMSA protocol for studying the cellular signal transduction pathways.

According to the protocols documented, a simple, economical and reproducible EMSA protocol was established, which was adopted in studying the activity of the nuclear transcription factors NF- $\mathrm{KB}$

\footnotetext{
* Author for correspondence
} 
and AP-1 in the mouse peritoneal macrophages after severe burns, and was compared with the other protocols.

\section{MATERIAL AND METHODS}

\section{Nucleic protein extraction}

The modification was made according to the report of Andrews and Faller (1991). The supernatants of 1 to $5 \times 10^{6}$ peritoneal macrophages in the culture plate were discarded and adherent cells were scrapped into $1.5 \mathrm{~mL}$ of the cold PBS. The cells were washed twice with the cold PBS. The following procedures were carried out at $4^{\circ} \mathrm{C}$. The pelleted cells were resuspended in $100 \mu \mathrm{L}$ of the cold Buffer A (10 mM HEPES-NaOH (pH 7.8), $15 \mathrm{mM} \mathrm{KCl}, 1 \mathrm{mM} \mathrm{MgCl}, 0.1 \mathrm{mM}$ EDTA, $1 \mathrm{mM}$ dithiothreitol, $1 \mathrm{mM}$ PMSF, $1 \mu \mathrm{g} / \mathrm{mL}$ leupeptin) by flicking the centrifuge tube. The cells were allowed to swell on the ice for $15 \mathrm{~min}$, and then vortexed for $10 \mathrm{sec}$ by adding $10 \mu \mathrm{L}$ of $10 \%$ Nonidet P40. The samples were centrifuged at $10000 \mathrm{~g}$ for $30 \mathrm{sec}$ at the room temperature and the supernatant containing cytosolic extract was collected and stored at $-70^{\circ} \mathrm{C}$ for other use. The pellet was resuspended in 50-100 $\mu \mathrm{L}$ (according to starting number of cells) of cold Buffer B (20 mM HEPES-NaOH (pH 7.9), $1.5 \mathrm{mM} \mathrm{MgCl} 2,0.42 \mathrm{M}$ $\mathrm{NaCl}, 0.2 \mathrm{mM}$ EDTA, $25 \%$ glycerol, $0.5 \mathrm{mM}$ dithiothreitol, $0.5 \mathrm{mM}$ PMSF, $1 \mu \mathrm{g} / \mathrm{mL}$ leupeptin) and incubated on the ice for $30 \mathrm{~min}$ for high-salt extraction. The cellular debris were removed by the centrifugation at $12000 \mathrm{~g}$ for $2 \mathrm{~min}$ and the supernatants (containing DNA binding proteins) were stored at $-70^{\circ} \mathrm{C}$.

\section{Nucleic protein quantification}

According to the Bradford method (1976), the protein quantification was conducted using a plate reader. For this, $50 \mu \mathrm{L}$ of the diluted sample was added into $500 \mu \mathrm{L}$ of the Coomassie bright blue protein quantification solution (CBBG-250 15mg, $95 \%$ ethanol $5 \mathrm{ml}, 85 \%$ phosphoric acid $10 \mathrm{~mL}$, appropriate volume of water was added to the total volume of $100 \mathrm{~mL}$, the resultant solution was subjected to filtration and adjustment of $\mathrm{pH}$ to 1.5). Then the solution was mixed and, 5 min later, pipetted in triplicate into a 96-well plate $(150 \mu \mathrm{L}$ per well). The controls were set using the multiproportionally diluted standard bovine serum albumin (from 1 to $0.0315 \mathrm{mg} / \mathrm{L}$ ) and blanks using distilled water. The absorbance was measured at $595 \mathrm{~nm}$ using a Bio-Rad Model 550 Plate Reader (USA). A linear regression equation, $\mathrm{Y}=\mathrm{ax}+\mathrm{b}$, was obtained. By such means, the sensitive range of 5 to $100 \mathrm{mg} / \mathrm{L}$ previously documented was raised to 1-30 mg /L (Hu et al., 2000).

\section{Probe labeling}

The sequence of the oligonucleotides used as DNA probes were: mouse NF- $\kappa \mathrm{B}$ consensus oligonucleotide (forward 5'- AGT TGA GGG GAC TTT CCC AGG C -3', reverse 5' - GCC TGG GAA AGT CCC CTC AAC T -3', synthesized by Sangon Biotechnology, China) and mouse AP-1 consensus oligonucleotide (forward 5'- CGC TTG ATG AGT CAG CCG GAA-3', reverse 5' - TTC CGG CTG ACT CAT CAA GCG -3', synthesized by the Sangon Biotechnology, China). Two sets of Eppendorf tubes (set A and set B) were aligned, in which 1 $\mu \mathrm{L}$ of oligonucleotide single-stranded probe was added (forward probe into set $\mathrm{A}$ and reverse probe into set $\mathrm{B}$; the concentration of both types of probes, $10 \mathrm{pmol} / \mu \mathrm{L})$, and then $1 \mu \mathrm{L}(10 \mathrm{U})$ of $\mathrm{T} 4$ polynucleotide kinase (Promega Corp, USA), $2 \mu \mathrm{L}$ of $10 \times \mathrm{T} 4$ buffer, $2.5 \mu \mathrm{L}$ of $\gamma$-phosphorus 32labeled adenosine triphosphate $\left(\gamma-\left[{ }^{32} \mathrm{p}\right]-\mathrm{ATP}\right)(3.9$ $\times 10^{5} \mathrm{~Bq} / \mu \mathrm{L}$, Yahui Corp, China), and $13.5 \mu \mathrm{L}$ of ribozyme-free redistilled water were added. Both the tubes were incubated at $37^{\circ} \mathrm{C}$ for $1 \mathrm{~h}$ and $68^{\circ} \mathrm{C}$ for $10 \mathrm{~min}$ to inactivate the $\mathrm{T} 4$ polynucleotide kinase. The solution in two tubes was mixed and incubated at $37^{\circ} \mathrm{C}$ for $1 \mathrm{~h}$ to let the probes combine into double strands. The obtained probes were stored at $-20^{\circ} \mathrm{C}$.

\section{Purification of probes by ethanol precipitation}

The bound products $40 \mu \mathrm{L}$ were added into an Eppendorf tube containing $10 \mu \mathrm{L}$ of $5 \mathrm{M}$ ammonium acetate and $100 \mu \mathrm{L}$ of the cold ethanol. The mixture was placed at $-20^{\circ} \mathrm{C}$ for $30 \mathrm{~min}$ and then centrifuged at $12000 \mathrm{~g}$ for $10 \mathrm{~min}$ at $4^{\circ} \mathrm{C}$. The supernatant was removed, and then $200 \mu \mathrm{L}$ of $1 \mathrm{M}$ ammonium acetate and $400 \mu \mathrm{L}$ of ethanol were added and mixed. The mixture was placed at $20^{\circ} \mathrm{C}$ for $30 \mathrm{~min}$ and the centrifugation was reperformed under the same conditions as described above. The supernatant was removed. The pellet was air dried, re-suspended in $100 \mu \mathrm{L}$ of TrisEDTA buffer (pH8.0), and then stored at $-20^{\circ} \mathrm{C}$ (Sambrook and Russell, 2001). 
Binding of probe to nucleic protein and electrophoresis

The binding assays were performed in $21 \mu \mathrm{L}$ of the binding reaction mixture containing $3 \mu \mathrm{g}$ of extracted nucleic protein, $17 \mu \mathrm{L}$ of DNA binding buffer (10 mM Tris-HCl (pH8.0), $50 \mathrm{mM} \mathrm{NaCl}$, $0.5 \mathrm{mM}$ EDTA (pH 8.0), $0.5 \mathrm{mM}$ DTT, $1 \mathrm{mM}$ $\mathrm{MgCl}_{2}, 2.5 \%$ Poly (dI-dC), $4 \%$ ( v/v) glycerol) and $1 \mu \mathrm{L}(1 \mathrm{ng} / \mu \mathrm{L})$ of ${ }^{32} \mathrm{p}$-labeled DNA probe. The mixture was incubated at room temperature for 30 min. Then $4 \mu \mathrm{L}$ of the loading buffer $(0.25 \%$ bromphenol blue, $0.25 \%$ xylene cyanol, $30 \%(\mathrm{v} / \mathrm{v})$ glycerol) was added. The reaction products were analyzed by the electrophoresis in a 5\% nondenaturing polyacrylamide gel with $0.5 \times$ Tris/borate/EDTA buffer at $110 \mathrm{~V}$ for $2 \mathrm{~h}$. The specificity of the binding was confirmed by the addition of a 100-fold excess of the unlabeled double-stranded oligonucleotides containing the mouse NF- $\mathrm{KB}$ site to separate reaction mixtures. As non-specific competition, a 100-fold excess of the cold oligonucleotide bearing the AP-1 binding site was added to separate the reaction mixtures. The competition reactions were incubated for 10 min before the addition of $1 \mu \mathrm{L}(1 \mathrm{ng} / \mu \mathrm{L})$ of the labeled oligonucleotide. After the electrophoresis, the gel containing the DNA-protein complexes was exposed to Kodak $\mathrm{X}$ film for $18 \mathrm{~h}$ at $-70^{\circ} \mathrm{C}$. The autoradiograms were quantified by the scanning densitometry with LabImage 2.6 software.

\section{RESULTS}

With the use of protein quantification by the modified Bradford method, the yield of the nucleic protein was 50 to $60 \mu \mathrm{g} / 10^{6}$ cells. As determined using a Beckman liquid scintillation counter, the isotope incorporation efficiency of the probes was 68 to $70 \%$, and the radioactivity of the labeled probes was $(1.7-2.7) \times 10^{3} \mathrm{~Bq} / \mu \mathrm{L}$. The EMSA images indicated a strong black band of free labeled-probes and DNA-protein binding bands of various gray scales. The negative control sample with no nucleic protein merely produced a band of free labeled probes, but no binding bands. With the specific competition, the binding band disappeared, demonstrating that the binding of the probes to nucleic protein was specific. The binding bands of different gray scales and area suggested the discrepancy in the activities of nuclear transcription factors (Fig 1 and Fig 2).

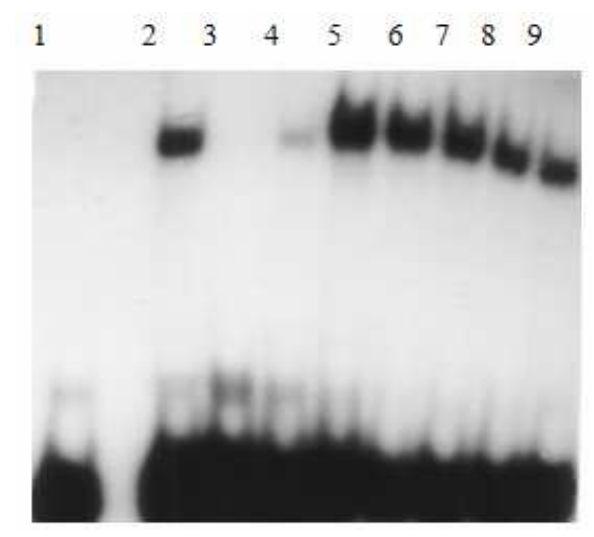

Figure 1 - Dynamic changes of NF- $\mathrm{KB}$ activity of mouse peritoneal macrophages after severe scald. Peritoneal macrophages $\left(1 \times 10^{6} / \mathrm{mL}\right)$ at different hours following thermal injury were incubated with $10 \mu \mathrm{g} / \mathrm{mL}$ lipopolysaccharide at $37^{\circ} \mathrm{C}$ for $2 \mathrm{~h}$. Then, nuclear extracts were prepared and assayed for NF- $\mathrm{KB}$ as described in materials and methods. 1: negative control; 2: non-specific competition; 3: 100-fold specific competition; 4: normal control; 5: $2 \mathrm{PBH}$; 6: $6 \mathrm{PBH}$; 7: $12 \mathrm{PBH}$; 8: $24 \mathrm{PBH}$; 9: 48 PBH. 


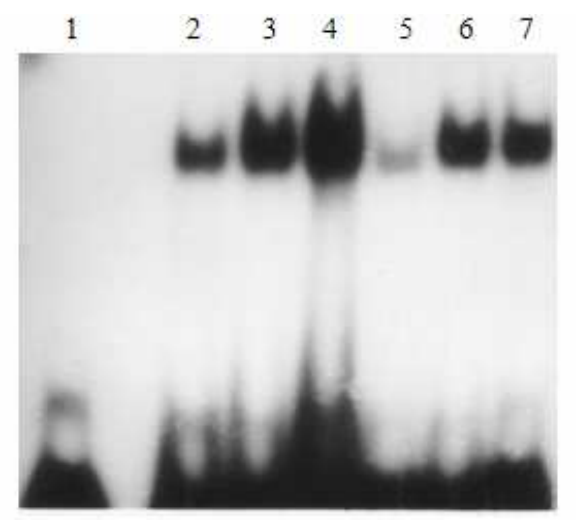

Figure 2 - Dynamic changes of AP-1 activity of mouse peritoneal macrophages after severe scald. Peritoneal macrophages $\left(1 \times 10^{6} / \mathrm{mL}\right)$ at different hours following thermal injury were incubated with $10 \mu \mathrm{g} / \mathrm{mL}$ lipopolysaccharide at $37^{\circ} \mathrm{C}$ for $2 \mathrm{~h}$. Then, nuclear extracts were prepared and assayed for AP-1 as described in materials and methods. 1: negative control; 2: normal control; 3: 2 PBH; 4: $6 \mathrm{PBH}$; 5: $12 \mathrm{PBH}$; 6: $24 \mathrm{PBH}$; 7: $48 \mathrm{PBH}$.

\section{DISCUSSION}

The EMSA is a technique used to analyze the activity of the intracellular nuclear transcription factor-DNA binding using nondenaturing polyacrylamide electrophoresis and radioautography. The nuclear transcription factors, a group of proteins, bind to certain nucleotide sequences in the promoters and enhancers of some genes, triggering the genetic transcription. The nuclear transcription factors, such as NF- $\mathrm{KB}$, AP-1 and CREB, play pivotal roles in the cellular signal transduction. Currently, the most common method for assaying the activity of nuclear transcription factors is EMSA, and its rationale is as follows: the nuclear transcription factors bind to the specific DNA probes to form the DNA-protein complexes, which slows the electrophoretic mobility. Accordingly, there is a lagged band behind the band of free probes on the radioautogram. The activity of the transcription factors can thus be semi-quantified according to the gray scale and size of the lagged band. Additionally, the specificity of the reaction can be tested using antibody super shift assay or specific competition assay. The complete EMSA procedures include extraction and quantification of the nucleic protein, labeling and purification of the probes, probe-protein binding, electrophoresis, and radioautography. The quantitative EMSA using the biotin-labeled probes has been reported to study RNA-protein interactions ( $\mathrm{Li}$ et al., 2004).
The novelty of the present protocols compared with the conventional EMSA are listed below.

The method described by Dignam et al (1983) to extract the nucleic protein was initially adopted, but that method required a whole day's time (time consuming), high-speed centrifugation (four times, at least $20 \mathrm{~min}$ for each), large numbers of cells (at least $10^{7} /$ sample), and tedious dialysis and precipitation. Moreover, any inadvertency cause the failure in the extraction. The modified procedure was according to Andrews and Faller (1991) and established a new protocol for the nucleic protein extraction, which required only $100 \mathrm{~min}$, two buffers, and small numbers of cells $\left(1 \times 10^{6} /\right.$ sample $)$, but yielded the similar results as Andrews and Faller's method (50-60 $\mu \mathrm{g}$ nucleic protein $/ 10^{6}$ cells).

It was thought that the key of the successful EMSA was in probe labeling. It is generally thought that the prime radioactivity of the labeled probes should be more than $1.1 \times 10^{3} \mathrm{~Bq} / \mu \mathrm{L}$. Under that condition, strong radioautograms and differences can be found in the DNA-protein binding bands. In this work initially doublestranded NF- $\mathrm{NB}$ and $\mathrm{AP}-1$ probes were labeled (Promega Corp, USA) for three times according to the company's instructions. But results of the radioactivity of the labeled probes were all lower than $2.2 \times 10^{2} \mathrm{~Bq} / \mu \mathrm{L}$, and no or faint radioautograms were found in the binding band. The precise causes were to be elucidated. Then single-stranded probe was labeled with $\gamma_{-}{ }^{32} \mathrm{P}$-ATP at their 5'-end, the mixture containing 
complementary single-stranded probe was incubated at $37^{\circ} \mathrm{C}$ for $1 \mathrm{~h}$ to get the doublestranded probes. In this way, the radioactivity of the probes was increased dramatically to (1.7-2.7) $\times 10^{3} \mathrm{~Bq} / \mu \mathrm{L}$, which ensured successful assays (Wang et al., 2005).

Except for the nucleic protein extraction and probe labeling above, poly (dI-dC) application, gel drying and radioautography were modified. Poly (dI-dC) is composed of deoxyinosine and deoxycytosine, which inhibits the binding of the labeled probes to nucleic protein non-specificity. At present, the amount of Poly (dI-dC) commonly used is 1 to $2 \mu \mathrm{g} / \mathrm{sample}$. The instructions by Promega Company recommend the use of $0.5 \mu \mathrm{g}$ of Poly (dI-dC) in $10 \mu \mathrm{L}$ of the reaction system. But this reagent is expensive. During the experiments according to the method described by Shenkar et al (1996), $0.4 \mu \mathrm{g}$ of Poly (dI-dC) for 25 $\mu \mathrm{L}$ of the reaction system produced satisfactory results. These results were not significantly different from those by the methods recommended by Promega Company in quality $(P>0.05, t$-test $)$, but brought a reduction in Poly (dI-dC) consumption by $70 \%$. Therefore, the present method would be economical. After the electrophoresis, the gel is usually dried, pressed, and subjected to the radioautography at ultra low temperatures. During the experiments, the process of gel drying was tedious, such as glacial acetic acid soaking and drying of the filter paper. Moreover, a gel-dryer was required. Since $\beta$ particles emitted by ${ }^{32} \mathrm{P}$ have enough energy to penetrate the $6 \mathrm{~mm}$-deep water or plastics, and Xray films $(1.7 \mathrm{MeV})$ (Tan et al., 2001), the step of gel drying could be skipped. There were no significant differences in the EMSA images with or without gel drying. Prior to the exposure to the film, the gel was striped and covered with refreshing membrane carefully, especially against the formation of the large air bubbles. To increase the exposure intensity, the sensitizing screens made of calcium tungstate should be used.

To conclude, this could be a modified EMSA for determination of the nuclear transcription factor activity. The method simplified the nucleic protein extraction procedures, elevated the radioactivity of the probes, skipped gel drying, lowered the reagent consumption and experimental expenditure, and thus has merited for wide applications.

\section{LIST OF ABBREVIATIONS}

\begin{tabular}{|c|c|}
\hline AP-1 & - activator protein-1 \\
\hline $\mathrm{Bq} / \mu \mathrm{L}$ & - becquerel/microliter \\
\hline CBBG-250 & - coomassie bright blue G-250 \\
\hline CREB & $\begin{array}{l}\text { - cAMP response element } \\
\text { binding protein }\end{array}$ \\
\hline DTT & - dithiothreitol \\
\hline EDTA & $\begin{array}{l}\text { - ethylenediamine tetraacetic } \\
\text { acid }\end{array}$ \\
\hline EMSA & $\begin{array}{l}\text { - electrophoretic mobility shift } \\
\text { assay }\end{array}$ \\
\hline MeV & - million electron volt \\
\hline $\mathbf{N F}-\kappa \mathbf{B}$ & - nuclear factor-kappaB \\
\hline PBH & - postburn hour \\
\hline PBS & - phosphate-buffered saline \\
\hline PMSF & $\begin{array}{l}\text { - phenylmethyl } \\
\text { sulfonylfluoride }\end{array}$ \\
\hline Poly (dI-dC) & $\begin{array}{l}\text { - poly (deoxyinosine } \\
\text { deoxycytosine) }\end{array}$ \\
\hline
\end{tabular}

\section{ACKNOWLEDGEMENTS}

This work was supported by the grants from the Military Ninth Five-year Instructive Topic (No: 96L042) and the National Natural Science Foundation of China (No: 30300452).

\section{RESUMO}

A determinação da alteração na mobilidade eletroforética (EMSA), o método de mais ampla utilização para o estudo das interações proteínaácidos nucléicos, é tediosa e difícil de dominar. De acordo com os protocolos dacumentados e com base em nossa prática, nós modificamos os diversos processos principais dessa determinação incluindo no que diz respeito a extração de proteiínas nucleicas, marcação das provas e radioautografia. A determinação modificada requer menor tempo, simplifica a extração de ácidos nucleicos, eleva a radioatividade da prova marcada, evita o processo tedioso de secagem do gel e produz claras imagens. Seus resultados são comparáveis, reproduzíveis e estáveis, merecendo, desse modo, ampla aplicação. 


\section{REFERENCES}

Andrews, N. C. and Faller, D. V. (1991), A rapid micropreparation technique for extraction of DNAbinding proteins from limiting numbers of mammalian cells. Nucleic Acids Research, 19, 2499.

Bradford, M. M. (1976), A rapid and sensitive method for the quantification of microgram quantities of protein utilizing the principle of protein-dye binding. Analytical Biochemistry, 72, 248-254.

Dahlberg, A. E.; Dingman, C. W. and Peacock, A. C. (1969), Electrophoretic characterization of bacterial polyribosomes in agarose-acrylamide composite gels. Journal of Molecular Biology, 41, 139-147.

Dignam, J. D.; Lebovitz, R. M. and Roeder, R.G. (1983), Accurate transcription initiation by RNA polymerase II in a soluable extract from isolated mammalian nuclei. Nucleic Acids Research, 11, 1475-1489.

Fried, M. G. and Crothers, D. M. (1981), Equilibria and kinetics of lac repressor-operator interactions by polyacrylamide gel electrophoresis. Nucleic Acids Research, 9, 6505-6524.

Garner, M. M. and Revzin, A. (1981), A gel eletrophoresis method for quantifying the binding of proteins to specific DNA regions: application to components of the Escherichia coli lactose operon regulatory system. Nucleic Acids Research, 9, 30473060 .

Hu, Y. B.; Peng, D. Z. and Huang, W. H. (2000), The dynamic changes of postburn complement activation and its effects on the secretory function of macrophages in severely burned mice. Chinese Journal of Burns, 16, 231-233.
Lane, D.; Prentki, P. and Chandler, M. (1992), Use of gel retardation to analyze protein-nucleic acid interation. Microbiological Reviews, 56, 509-528.

Li, Y.; Jiang, Z. Z.; Chen, H. X. and Ma, W. J. (2004), A modified quantitative EMSA and its application in the study of RNA-protein interactions. Journal of Biochemical and Biophysical Methods, 60, 85-96.

Sambrook, J. and Russell, D. W. (2001), Molecular Cloning: A Laboratory Manual, $3^{\text {rd }}$ ed. Cold Spring Harbor Laboratory, New York, Chinese Version, pp. 827.

Shaup, H. W.; Green, M. and Kurland, C. G. (1970), Molecular interactions of ribosomal components: Identificaton of RNA binding sites for individual 30S ribosomal proteins. Molecular and General Genetics, 109, 193-205.

Shenkar, R.; Schwartz, M. D.; Terada, L. S.; Repine, J. E.; McCord, J. and Abraham, E. (1996), Hemorrhage activates $\mathrm{NF}-\kappa \mathrm{B}$ in murine lung mononuclear cells in vivo. The American Journal of Physiology, 270, 729735.

Tan, X. D.; Liu, Y. F.; Li, Y. M.and He, S.G. (2001), Application of autoradiography in study of gold storaged transplant organs. Journal of China Medical University, 30, 101-102.

Wang, Y.; Fang, Y. F.; Huang, W. H.; Zhou, X.; Wang, M. H.; Zhong, B. and Peng, D. Z. (2005), Effect of sinomenine on cytokine expression of macrophages and synoviocytes in adjuvant arthritis rats. Journal of Ethnopharmacology. 98, 37-43.
Received: July 18, 2006; Revised: January 25, 2007; Accepted: June 04, 2008. 